\title{
Incidence of Peste Des Petits Ruminants Virus infection in Small Ruminants of Saurashtra Region of Gujarat State
}

\author{
M. M. Tajpara ${ }^{1}$, A. N. Kanani ${ }^{2}$, H. H. Savsani ${ }^{1}$, J. B. Kathiriya ${ }^{1}$,

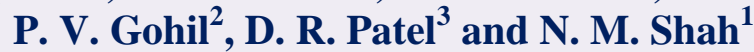 \\ ${ }^{1}$ College of Veterinary Science and Animal Husbandry, Junagadh Agricultural University, \\ Junagadh, Gujarat, India \\ ${ }^{2}$ Department of Animal Husbandry, Animal Disease Investigating Laboratory, Gujarat State, \\ Ahmedabad, Gujarat, India \\ ${ }^{3}$ College of Veterinary Science and AH, Navsari Agricultural University, \\ Navsari, Gujarat, India \\ *Corresponding author
}

\section{A B S T R A C T}

\section{Keywords}

Peste Des Petits Ruminants (PPR), Sandwich-ELISA (S-ELISA), Small Ruminants

Article Info

\section{Accepted:}

15 June 2021 Available Online: 10 July 2021
A total of 119 different clinical samples (nasal swab, conjunctival swabs, oral swabs and tissue samples) from sheep and goats were collected from the area under study for detection of PPR antigen by Sandwich-ELISA. Out of 119 clinical samples, 37 samples were found positive in small ruminants by S-ELISA, giving an overall incidence rate of $31.09 \%$ (37/119). In sheep $33.33 \%$ and goats $30.52 \%$ samples were detected positive. District wise incidence of PPRV in small ruminants differed non significantly. It was recorded in Bhavnagar (33.90\%), Amreli $(29.41 \%)$ and Rajkot (26.92\%) districts. Month wise incidence of PPRV in small ruminants differed non significantly. It was recorded in month of October (29.41\%), November (31.58\%) and December (33.33\%). Age wise incidence of PPRV in small ruminants differed non significantly. It was recorded in below 1 year of age group (39.29\%), 1 to 2 year (28.95\%) and above 2 years of age (16.00\%). Sex wise incidence of PPRV in small ruminants differed non significantly. It was recorded in male $(30.43 \%)$ and female $(31.51 \%)$.Breed wise incidence of PPRV in small ruminants differed non significantly. It was recorded $(36.62 \%)$ in nondescript breed and $(22.92 \%)$ in descript breed. Out of 119 clinical samples, 37 samples including 13 Nasal swabs, 3 conjunctival swabs, 7 oral swabs and 14 tissue were found positive. PPRV antigen was detected by S-ELISA in tissue $(66.67 \%)$, oral swab (43.75\%), nasal swab (20.97\%) and conjunctival swab $(15.00 \%)$. Most suitable sample for virus isolation was tissue and oral sample.

\section{Introduction}

At present, PPR is enzootic in India and out break occur regularly among small ruminants throughout the country and the overall prevalence of PPRV was reported within the range of $20-60 \%$ (Singh et al., 2004). The reports documented the presence of PPRV in Rajasthan in the north (Kataria et al., 2007) and Maharashtra in the west (Santhosh et al., 
2009) and across the southern peninsula (Raghavendra et al., 2008). But, presence of PPR was studied and confirmed from Gujarat byHinsu et al., (2001) and later on by other workers (Kanani et al., 2006; Chauhan et al., 2009; Sharma et al., 2015; Patel et al., 2017; Sakhare, 2019).

Conventional serological tests like Agar Gel Immunodiffusion Test(AGID), Counter Immuno Electrophoresis test (CIEP) etc. often fail to differentiate PPRV and RPV infections. The techniques available to differentiate PPR from RP are virus neutralization test (VNT), Complementary DNA (cDNA) probes (Diallo et al., 1989), Virus specific monoclonal antibodies in an immunocapture enzyme linked immunosorbent assay (ELISA) (Libeau et al., 1995) and haemagglutination using piglet or chicken red blood cells (Shaila et al., 1996).

The lower relative sensitivity observed in RTPCR might be attributed to nature of PPRV genome which shows higher rate of transcription of $\mathrm{N}$ gene. Thus, the abundance of nucleoprotein, which is targeted in sandwich-ELISA, may result in relatively higher sensitivity of the ELISA as compared to $\mathrm{F}$ gene and $\mathrm{N}$ gene RT-PCR. (George, 2002). Moreover, studying the prevalence in the target population is paramount importance to formulate and implement a proper strategic disease control vaccination program in a particular geographical area with a long-term plan to eradicate PPR by 2030.

Considering the above facts and importance of disease on economics of sheep and goat farming, a present research study "Detection of Peste Des Petits Ruminants Virus in Sheep and Goats of Saurashtra region of Gujarat by sandwich -ELISA" was undertaken with overall, location wise, species wise, sex wise and age wise incidence and sample wise positivity of $P P R V$.

\section{Materials and Methods}

\section{Samples Collection}

A totalof119samples (goats -95 and sheep -24) including swabs (nasal, oral and conjunctival swabs) and tissue(lungs, Intestine, spleen, etc.) samples were collected from clinically ailing animals showing symptoms suggestive of PPR in viral transport medium (VTM) i.e. Dulbecco's Modified Eagle's Medium (DMEM)from different districts of Saurashtra region of Gujarat (Table 1 and Fig. 1\&2).

\section{Sandwich-ELISA Kits}

PPR Sandwich-ELISA kit for PPRV antigen detection along with the user manual was obtained from Division of Virology, IVRI, Mukteswar and supplied by Animal Disease Investigating Laboratory, Ahmedabad.

\section{Test Protocol}

Dispensed $100 \mu \mathrm{l}$ of diluted capture antibody (1:4000) in all the wells of ELISA module supplied with the kit. Covered the plate with a lid and incubated for one hour at $370 \mathrm{C}$ in a ordinary incubator with continuous shaking on orbital shaker.

At the end of incubation period, contents of the plate were discarded by inverting the plate over sink and jerking it down with a single motion of hand. The plate was washed three times with wash buffer (PBS diluted four times with distilled water containing $0.05 \%$ Tween-20) and dried by gently tapping over filter paper.

After washing, following reagents were added very carefully step by step:

$50 \mu \mathrm{l}$ of blocking buffer in all the wells.

$50 \mu \mathrm{l}$ of additional blocking buffer to antigen blank (B) wells (A1-H1). 
$50 \mu 1$ of clinical samples in vertical duplicates as per the template provided with the kit (A3/B3, C3/D3 and so on).

$50 \mu \mathrm{l}$ of positive reference $(\mathrm{C}+)$ antigen in four designated wells (A2/B2, C2/D2).

$50 \mu \mathrm{l}$ of negative reference (C-) antigen in four designated wells (E2/F2, G2/H2).

Contents of the well were mixed by gently tapping the sides of the plate. The plate was covered with a lid and incubated at $37{ }^{\circ} \mathrm{C}$ for one hour on an orbital shaker with continuous shaking at moderate speed.

At end of incubation repeated the discard and washing procedures as in step

Diluted detection antibody $(100 \mu \mathrm{l})$ was added in all the wells using multichannel pipette. The plate was covered with a lid and incubated at $37^{\circ} \mathrm{C}$ for one hour on an orbital shaker with continuous shaking at moderate speed.

At the end of incubation, the plate was taken out of the incubator and discard and washing was performed as described in step b).

Diluted (1:1000) anti-mouse conjugate (100 $\mu$ l) was added in all the wells. The plate was covered with a lid and incubated at $37^{\circ} \mathrm{C}$ for one hour on an orbital shaker with continuous shaking at moderate speed.

At the end of incubation, the plate was taken out of the incubator and discard and washing was performed as described in step b).

A freshly prepared OPD substrate solution $(100 \mu \mathrm{l})$ was added in each well and the plate was incubated for 10 to $20 \mathrm{~min}$ at $37^{\circ} \mathrm{C}$ without shaking or till the colour developed in positive reference $(\mathrm{C}+)$ wells.

Stopping solution $(100 \mu \mathrm{l})$ was added to all the wells and the plate was gently tapped to mix the fluids. The plate was read in an ELISA plate reader (Multiskan Plus, Lab System) at492 $\mathrm{nm}$.

\section{Interpretation of test results}

\section{Cutoff}

For calculation of cutoff point, four antigen blank wells (B) having extreme OD values (two wells of lowest OD values and two wells of highest values) were excluded. The remaining four wells having intermediate OD values were considered. Cut off was taken as two times the mean OD of these intermediate wells. Samples having more OD than the cut off were taken as positive, while samples having less OD than the cut off were taken as negative. Further, a sample positive in both the duplicate wells was taken as positive. A sample positive in one well and negative in other duplicate well was retested before recording the results.

\section{Results and Discussion}

A total of 119 different clinical samples (nasal swabs, conjunctival swabs, oral swabs and tissue samples) from goats and sheep were collected from Jamnagar, Rajkot, Amreli, Surendranagar and Bhavnagar districts of Saurashtra region of Gujarat for detection of PPR antigen by Sandwich ELISA. The district-wise, month-wise, age wise and sex wise details are depicted in Table2.

\section{Overall incidence}

Clinical samples from goat and sheep were available from 3 districts of Saushartra like Rajkot, Amreli and Bhavnagar. Goat clinical sample number (95) were from Bhavnagar (45), Amreli (28) and Rajkot (22) districts. Whereas, sheep clinical samples, which were relatively a less number (24) were only from Bhavnagar (14), Amreli (6) and Rajkot (4) 
districts (Table 1). Out of 119clinical samples, 37 samples were found positive in small ruminants by S-ELISA, giving an overall incidence rate of 31.09 percent. In Goat, $30.52 \%$ (29/95) samples were detected positive whereas in sheep $33.33 \%$ (8/24) cases were confirmed as positive.

Our findings of goats are lower than findings of earlier reports where antigens could be detected in $66.7 \%, 60 \%, 55.55 \%, 54.54 \%$ and $61.32 \%$ cases by Malik et al., (2011), Tiwari (2004), Mahajan et al., (2013) and Sakhare (2019) respectively. Significantly higher antigen detection was reported by Nagraj (2006) and Chaudhary et al., (2009) in Gujarat (India) and their values were $81 \%$ and $83.33 \%$, respectively. In our finding low incidence rate of PPR was noted due to PPR control programme in Gujarat state by vaccination.

\section{Species wise incidence of PPRV antigen}

Species wise incidence was observed statistically non-significant. Species wise analysis of data reveled higher incidence of PPR infection in sheep than goat. In Goat $30.52 \%(29 / 95)$ were positive whereas in sheep $33.33 \%(8 / 24)$ cases were confirmed as positive by S-ELISA (Fig. 3).

Similar to our results, some reports also indicate high incidence in sheep like Nagraj (2006) found $(83.33 \%)$ sheep and $(80 \%)$ goats and Chaudhary (2009) recorded (100\%) sheep and $(92.4 \%)$ goats positive for PPRV by SELISA in Gujarat. In contrast to our study Tiwari (2004) found higher incidence of PPR in Goat than Sheep in Gujarat. Chauhan (2009) founded that $9.61 \%$ incidence rate of PPR in sheep at Saurashtra region (Rajkot).

In India, Mahajan et al.,(2013) also noted a higher incidence of PPR infection in goats than sheep. Similarly, Abubakar et al., (2008) reported that outbreaks of PPR in Pakistan were more severe in goats than in sheep.

Lefevre and Diallo, (1990) who opined that goats are severely affected while sheep generally undergo a mild form. In some outbreaks, goats are not affected, while sheep succumb with high rates of mortality and morbidity (Yesilbag et al., 2005). However, reports detailing an increased susceptibility of sheep and goat population and outbreaks affecting sheep and goat populations have been equally reported (Chauhan et al., 2009).

Conclusively, there is no indication of the existence of PPRV variants more adapted to one than to another small ruminant species (Diallo, 2003). Absence of disease in sheep can be explained on the basis of a particular resistance of the local species and/or a loss of virulence of the PPRV strains for sheep. However, a systemic study involving large number of samples from sheep and goats coupled with well-designed experimental study may yield a scientific clue to the species wise more or less incidence of PPR in sheep and goat.

\section{District wise incidence of PPRV}

District wise incidence of PPRV was statistically non-significant. The incidence in case of goats was higher in Bhavnagar 33.33\% (15/45) followed by Amreli 28.57\% (8/28) and Rajkot $27.27 \%(6 / 22)$. While, in case of sheep antigen was detected in Bhavnagar35.71\% (05/14) followed by Amreli $33.33 \%$ (2/6) and Rajkot 25.00\% (1/4) (Table $1)$.

Tiwari (2004) studied variation of PPR incidences at two locations namely, Patan (55\%) and Vadodara (80\%) of Gujarat state. Also, Choudhary (2009) recorded highest incidence $(100 \%)$ of PPR virus in both Bhavnagar and Gandhinagar districts, whereas 
least incidence (60\%) was reported in Rajkot district. Sakhare (2019) recorded highest incidence of PPR in goat at Navsari (66.94\%) than Surat $(50.00 \%)$ district.

Location wise variation in morbidity rate (29.2-80\%) observed by Kulkarni, et al., (1996) during outbreaks of PPR at 9 different locations in Maharashtra.

\section{Month wise incidence of PPRV}

In the present study, month wise incidence of PPRV was statistically non-significant. Percent PPR positive goat cases observed were highest in the month of November(19) followed by October(8) and December (2). Percent PPR positive sheep cases observed were highest in the month of November(5) followed by October(2) and December (1).

Overall small ruminant percent PPR positive cases observed were highest in the month of November(24) followed by October(10) and December (3)

These findings can be compared with the report of Balamurugan et al., (2012) who reported the seasonal influence on PPR outbreaks in India i.e. PPR outbreaks are most frequent during cold dry months (Oct. to Dec.). Sakhare (2019) recorded that PPR outbreak in South Gujarat during August to February month.

The highest frequency of PPR outbreaks in Pakistan during the first and last quarter of the year with highest in the month of March. Additionally, PPR can also occur mostly during the cool, dry season in most endemic areas of Africa. The reason for the high incidence of PPR in these months may be the climatic factors that are favorable for the survival and spread of the virus may also contribute to the seasonal occurrence of PPR outbreaks (Abubakar et al., 2017).
PPR outbreaks have been linked to the introduction of new animals into flocks since the animals are usually under stress due to traveling over long distances (Balamurugan, et al., 2014). During their migration, these animals frequently infect local populations along the migration route and may be one of the reasons for the higher frequency of PPR outbreaks with increased susceptibility (Singh et al., 2004). The infected animals help to maintain viral circulation throughout the year via frequent animal to animal transmission.

Confinement and restricted movement of the animals, due to rainy seasons in tropical countries, may affect the nutritional status of the animals and hence predispose them to PPRV infection (Munir et al., 2015).

\section{Age wise incidence of PPRV}

In present study age wise incidence of PPRV antigen positivity was statistically nonsignificant among the different age groups. The viral antigen was detected in goat $38.64 \%$ (17/44) in below 1 year of age, followed by $29.03 \%(9 / 31)$ in $1-2$ years of age and $15.00 \%$ $(3 / 20)$ in above 2 years of age group. The viral antigen was detected in sheep $41.67 \%(5 / 12)$ in below 1 year of age, followed by $28.57 \%$ $(2 / 7)$ in $1-2$ years of age and $20.00 \%(1 / 5)$ in above 2 years of age group. The overall viral antigen was detected in small ruminant $39.29 \%(22 / 56)$ in below 1 year of age, followed by $28.95 \%(11 / 38)$ in $1-2$ years of age and $16.00 \%(4 / 25)$ in above 2 years of age group.

The findings of present study are in the line of previous reports published by Tiwari (2004) who found out of the 25 animals, five, eight, nine and three animals belonged to age groups of $0-24,24-48,48-72$, and $>72$ months, respectively, showing the respective incidence of PPRV as 100, 62.50, 44.44 and 33.33 per cent in Gujarat as per age grouping. 
Mahajan et al., (2013) from India recorded highest incidence of PPR $(83.33 \%)$ in young sheep/goat having age of 0-6 months, followed by $6-12$ months $(66.66 \%)$ and lowest $(31.35 \%)$ in adults having age more than 12 months in Jammu \& Kashmir.

Similar to our results, highest case fatality rate was observed by Mahajan et al., (2017) in goats of 3-6 months age group as compared to adults in two districts of Punjab (India) state affecting migratory flocks of goats.

Corroborating reports was also reported from other countries of higher incidence in $<6$ months of age and severe disease in sheep and goat by El-Rahim et al., (2010) in Kalubia province of Egypt.

\section{Sex wise incidence of PPRV antigen}

In the present study incidence of PPRV viral antigen was statistically non-significant between sexes. Accordingly, 30.77\% (12/39) male goats and $30.36 \%$ (17/56) female goats showed positivity against PPRV antigen. Whenever, 35.29\% (6/17) female sheep and $28.57 \%$ (2/7) male sheep showed positivity against PPRV antigen. Overall, $31.51 \%$
(23/73) female small ruminant and $30.43 \%$ (14/46) male small ruminant showed positivity against PPRV antigen.

The present study finding of high incidence rate in male corroborate with Sakhare (2019) from South Gujarat observed $69.23 \%$ male goat were positive as compare to $56.96 \%$ female goat. Opposite to our finding, Mahajan et al., (2013) from India observed 80 per cent females were positive as compared to 54.54 per cent males in case of goat.

Our findings of nearby equal incidence in male \& female corroborate with Afera et al., (2014) who reported nearly equal percent prevalence of the disease in male and female goats which was 47.4 per cent (28/59) and 47.5 per cent $(86 / 181)$, respectively in selected sites of Ethiopia. However, data from Pakistan reported no important relationship between males and females, with respect to susceptibility to gender (Kozat and Sepehrizadeh, 2017).

Male Goats are sold for meat purpose and retain female for future breeding this may be reason for low incidence in male (Mohapatra, 2015).

Table.1 District wise detection of PPR antigen by S-ELISA

\begin{tabular}{|c|c|c|c|c|c|c|c|}
\hline \multirow{2}{*}{$\begin{array}{c}\text { Sr. } \\
\text { No. }\end{array}$} & $\begin{array}{c}\text { Place of } \\
\text { Sample } \\
\text { collection }\end{array}$ & \multicolumn{2}{|c|}{ Species of the animals } \\
\cline { 3 - 9 } & Tested & Positive & Tested & Positive & Tested & Positive \\
\hline 01 & Rajkot & 22 & $6(27.27)$ & 4 & $1(25.00)$ & 26 & $7(26.92)$ \\
\hline 02 & Amreli & 28 & $8(28.57)$ & 6 & $2(33.33)$ & 34 & $10(29.41)$ \\
\hline 03 & Bhavnagar & 45 & $15(33.33)$ & 14 & $5(35.71)$ & 59 & $20(33.90)$ \\
\hline & Total & $\mathbf{9 5}$ & $\mathbf{2 9}(\mathbf{3 0 . 5 2})$ & $\mathbf{2 4}$ & $\mathbf{8}(\mathbf{3 3 . 3 3})$ & $\mathbf{1 1 9}$ & $\mathbf{3 7}(\mathbf{3 1 . 0 9})$ \\
\hline & & $\chi^{2}=0.328(\mathrm{P}>0.05)$ & $\chi^{2}=0.160(\mathrm{P}>0.05)$ & $\chi^{2}=0.473(\mathrm{P}>0.05)$ \\
\hline
\end{tabular}

Note: Figures in parentheses indicate percentage 
Table.2 Months, Age and Sex wise PPR virus prevalence in goats and sheep.

\begin{tabular}{|c|c|c|c|c|c|c|}
\hline \multirow[t]{3}{*}{ Particulars } & \multicolumn{4}{|c|}{ Species of the animals } & \multirow{2}{*}{\multicolumn{2}{|c|}{ Total }} \\
\hline & \multicolumn{2}{|c|}{ Goat } & \multicolumn{2}{|c|}{ Sheep } & & \\
\hline & Tested & Positive & Tested & Positive & Tested & Positive \\
\hline \multicolumn{7}{|c|}{ 1.Months } \\
\hline October & 27 & $8(29.63)$ & 7 & $2(28.57)$ & 34 & $10(29.41)$ \\
\hline November & 62 & $\begin{array}{c}19 \\
(30.65)\end{array}$ & 14 & $5(35.71)$ & 76 & $24(31.58)$ \\
\hline December & 6 & $2(33.33)$ & 3 & $1(33.33)$ & 9 & $3(33.33)$ \\
\hline Total & 95 & $\begin{array}{c}29 \\
(30.52)\end{array}$ & 24 & $8(33.33)$ & 119 & 37 (31.09) \\
\hline \multicolumn{3}{|c|}{$\chi^{2}=0.033(\mathrm{P}>0.05)$} & \multicolumn{2}{|c|}{$\chi^{2}=0.107(\mathrm{P}>0.05)$} & \multicolumn{2}{|c|}{$\chi^{2}=0.074(\mathrm{P}>0.05)$} \\
\hline \multicolumn{7}{|c|}{ 2. Age } \\
\hline$<1$ Year & 44 & $\begin{array}{c}17 \\
(38.64)\end{array}$ & 12 & $5(41.67)$ & 56 & $22(39.29)$ \\
\hline 1-2 Year & 31 & $9(29.03)$ & 7 & $2(28.57)$ & 38 & $11(28.95)$ \\
\hline$>2$ Year & 20 & $3(15.00)$ & 5 & $1(20.00)$ & 25 & $4(16.00)$ \\
\hline Total & 95 & $\begin{array}{c}29 \\
(30.53)\end{array}$ & 24 & $8(33.33)$ & 119 & $37(31.09)$ \\
\hline \multicolumn{3}{|c|}{$\chi^{2}=3.670(\mathrm{P}>0.05)$} & \multicolumn{2}{|c|}{$\chi^{2}=0.847(\mathrm{P}>0.05)$} & \multicolumn{2}{|c|}{$\chi^{2}=4.494(\mathrm{P}>0.05)$} \\
\hline \multicolumn{7}{|c|}{ 3. Sex } \\
\hline Male & 39 & $\begin{array}{c}12 \\
(30.77)\end{array}$ & 7 & $2(28.57)$ & 46 & $14(30.43)$ \\
\hline Female & 56 & $\begin{array}{c}17 \\
(30.36)\end{array}$ & 17 & $6(35.29)$ & 73 & $23(31.51)$ \\
\hline \multirow[t]{2}{*}{ Total } & 95 & $\begin{array}{c}29 \\
(30.53)\end{array}$ & 24 & $8(33.33)$ & 119 & 37 (31.09) \\
\hline & \multicolumn{2}{|c|}{$\chi^{2}=0.0018(\mathrm{P}>0.05)$} & \multicolumn{2}{|c|}{$\chi^{2}=0.100(\mathrm{P}>0.05)$} & \multicolumn{2}{|c|}{$\chi^{2}=0.015(\mathrm{P}>0.05)$} \\
\hline
\end{tabular}

Note: Figures in parentheses indicate percentage.

Table.3 Breed wise incidence of PPRV antigen

\begin{tabular}{|c|c|c|c|c|c|c|c|}
\hline $\begin{array}{c}\text { Breed } \\
\text { (Goat) }\end{array}$ & $\begin{array}{c}\text { No. of } \\
\text { tested }\end{array}$ & $\begin{array}{c}\text { No. of } \\
\text { positive }\end{array}$ & $\begin{array}{c}\text { Breed } \\
\text { (Sheep) }\end{array}$ & $\begin{array}{c}\text { No. of } \\
\text { tested }\end{array}$ & $\begin{array}{c}\text { No. of } \\
\text { positive }\end{array}$ & $\begin{array}{c}\text { Total } \\
\text { No. of } \\
\text { tested }\end{array}$ & $\begin{array}{c}\text { Total No. } \\
\text { of positive }\end{array}$ \\
\hline Zalawadi & 10 & 2 & Marwari & 3 & 0 & 13 & 2 \\
\hline Gohilwadi & 31 & 8 & Patanwadi & 4 & 1 & 35 & 9 \\
\hline TD & 41 & $10(24.39)$ & TD & 7 & $1(14.29)$ & 48 & $11(22.92)$ \\
\hline ND & 54 & $19(35.19)$ & ND & 17 & $7(41.18)$ & 71 & $26(36.62)$ \\
\hline G. Total & $\mathbf{9 5}$ & $\mathbf{2 9}$ & Total & $\mathbf{2 4}$ & $\mathbf{8}$ & $\mathbf{1 1 9}$ & $\mathbf{3 7}$ \\
\hline \multicolumn{2}{|c|}{$\chi^{\mathbf{2}=\mathbf{1 . 2 8 1}}(\mathbf{P}>\mathbf{0 . 0 5})$} & \multicolumn{2}{|c|}{$\chi^{2}=1.613(\mathrm{P}>0.05)$} & $\chi^{2}=2.51(\mathrm{P}>0.05)$ \\
\hline
\end{tabular}

Note: Figures in parentheses indicate percentage. TD: Total Descript, ND: Non-Descript 
Table.4 Sample wise PPR antigen detection by S-ELISA

\begin{tabular}{|c|c|c|c|c|c|c|c|}
\hline \multirow{3}{*}{$\begin{array}{l}\text { Sr. } \\
\text { No. }\end{array}$} & \multirow[t]{3}{*}{ Type of samples } & \multicolumn{4}{|c|}{ Species of the animals } & \multirow{2}{*}{\multicolumn{2}{|c|}{ Total }} \\
\hline & & \multicolumn{2}{|c|}{ Goat } & \multicolumn{2}{|c|}{ Sheep } & & \\
\hline & & Tested & Positive & Tested & Positive & Tested & Positive \\
\hline 01 & Nasal swabs & 40 & $7(17.5)$ & 22 & $6(27.27)$ & 62 & $13(20.97)$ \\
\hline 02 & Conjunctival swabs & 20 & $3(15.00)$ & 0 & 0 & 20 & $3(15.00)$ \\
\hline 03 & Oral swab & 16 & $7(43.75)$ & 0 & 0 & 16 & $7(43.75)$ \\
\hline 04 & *Tissue Table 4-A & 19 & $12(63.16)$ & 2 & $2(100)$ & 21 & $14(66.67)$ \\
\hline \multirow{2}{*}{\multicolumn{2}{|c|}{ Total }} & 95 & $29(30.53)$ & 24 & $8(33.33)$ & 119 & 37 (31.09) \\
\hline & & \multicolumn{2}{|c|}{$\chi^{2}=16.333 *(\mathrm{P}<0.05)$} & & & \multicolumn{2}{|c|}{$\chi^{2}=18.984 *(\mathrm{P}<0.05)$} \\
\hline
\end{tabular}

Note: Figures in parentheses indicate percentage.

Table.4A Tissue wise PPR antigen detection by S-ELISA

\begin{tabular}{|c|c|c|c|c|c|c|c|}
\hline \multirow{3}{*}{$\begin{array}{c}\text { Sr. } \\
\text { No. }\end{array}$} & \multirow[t]{3}{*}{ Type of tissue } & \multicolumn{4}{|c|}{ Species of the animals } & \multirow{2}{*}{\multicolumn{2}{|c|}{ Total }} \\
\hline & & \multicolumn{2}{|c|}{ Goat } & \multicolumn{2}{|c|}{ Sheep } & & \\
\hline & & Tested & Positive & Tested & Positive & Tested & Positive \\
\hline 01 & Lung & 9 & $8(88.89)$ & 1 & $1(100)$ & 10 & $9(90.00)$ \\
\hline 02 & Trachea & 4 & $2(50.00)$ & 0 & 0 & 4 & $2(50.00)$ \\
\hline 03 & Spleen & 3 & $1(33.33)$ & 0 & 0 & 3 & $1(33.33)$ \\
\hline 04 & Intestine & 3 & $1(33.33)$ & 1 & $1(100)$ & 4 & $2(50.00)$ \\
\hline \multirow{2}{*}{\multicolumn{2}{|c|}{ Total }} & 19 & $12(63.16)$ & 2 & $2(100)$ & 21 & $14(66.67)$ \\
\hline & & \multicolumn{2}{|c|}{$\chi^{2}=5.15(\mathrm{P}>0.05)$} & & & \multicolumn{2}{|c|}{$\chi^{2}=4.95(\mathrm{P}>0.05)$} \\
\hline
\end{tabular}

Note: Figures in parentheses indicate percentage.

Fig.1 Nasal Discharge from Sheep

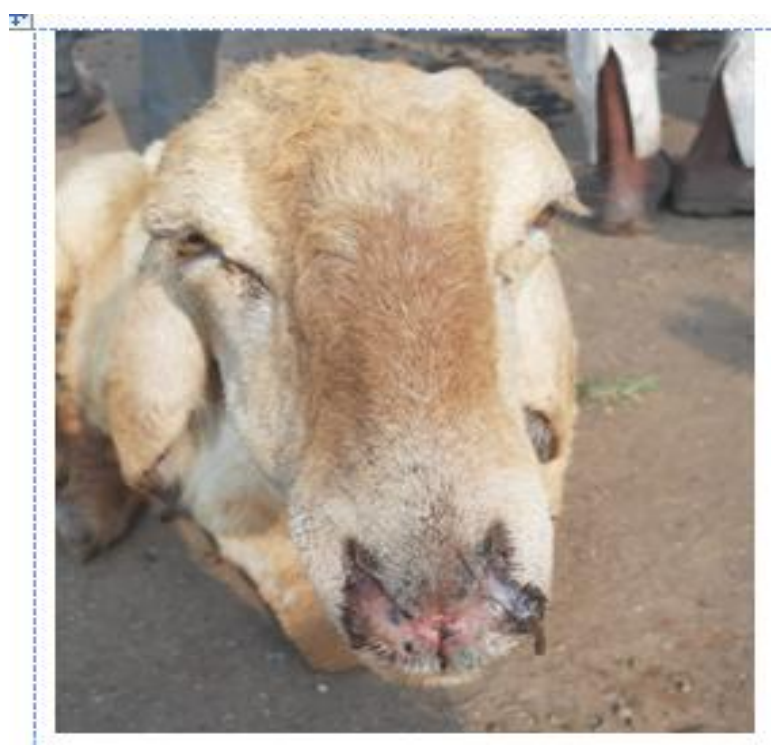

Fig.2 Mucopurulent Nasal Discharge from Goat

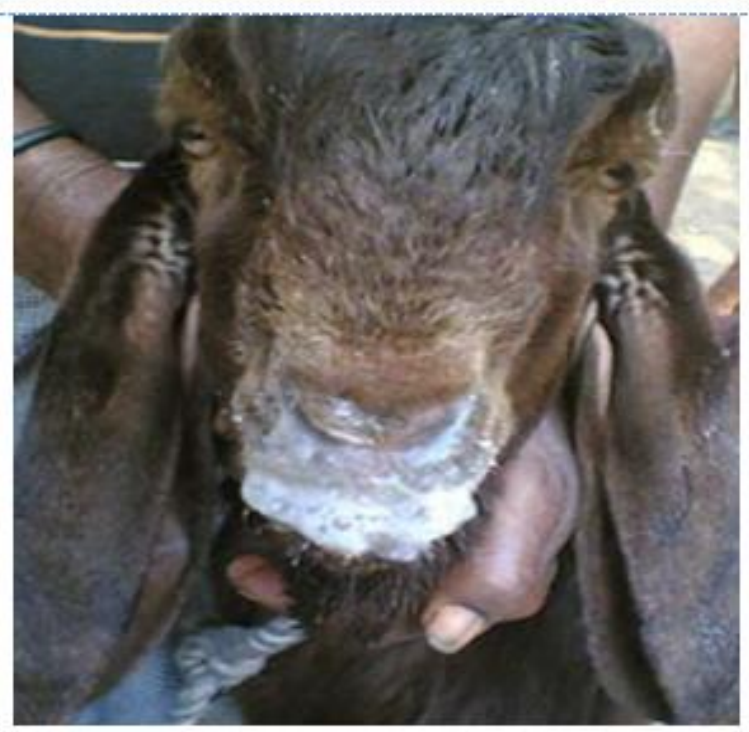


Fig.3 Sandwich ELISA for detection of PPR Antigen in sheep \& Goats (A1 to H1:- Antigen blank wells, A2 to D2:- Positive control, E2 to H2:- Negative control, A3 to D3,G3,H3,E4,F4,C5,D5,G6,H6,E7,F7,A8,B8,E9,F9,A10,B10,C11,D11,E12,F12:-Positive sample, Rest of wells are negative sample)

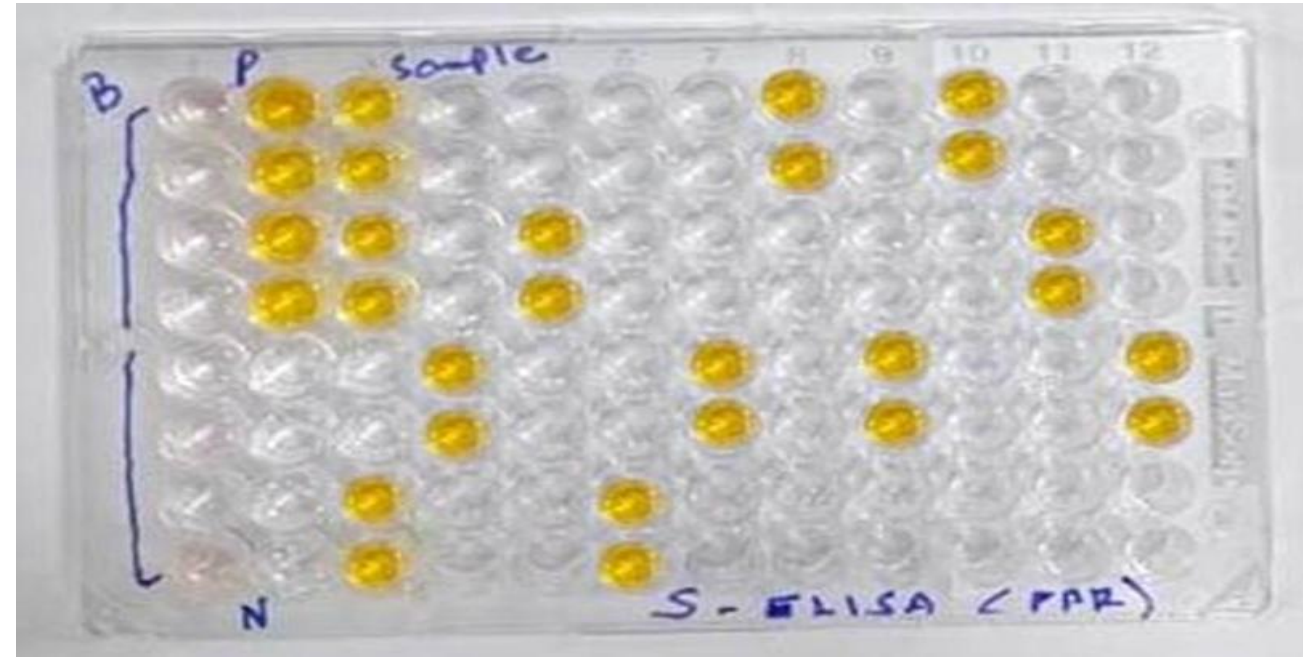

\section{Breed wise incidence of PPRV antigen}

In the present study incidence of PPRV viral antigen was statistically non-significant between Descript \& Non-Descript breed of small ruminant. Out of 119 clinical samples, 37 (31.09\%) samples including 29 goats and 8 sheep were found positive. Out of 29 clinical positive samples of goat, 19 Non-descript breed, 8 Gohilwadi, 2 Zalawadi breed of goat was found positive. Out of 8 clinical positive samples of sheep, 7 Non-descript breed, 1 patanwadi breed of sheep was found positive (Table 3).

The present study finding corroborate with Chauhan et al., (2011) reported that seroprevalence was highest in Non-descript goats $(46.18 \%)$ than Mehsani breed (40.77\%).

Contrary to our finding Abhijit et al., (2005) reported that the prevalence of the PPR infection in goats was found to be highest in Jamunapari breed (52\%) as compared to Black Bengal (30\%) and non-descript breeds (28\%). Rahman et al., (2015) reported that the prevalence of PPR was higher in Black Bengal goats than in Jamunapari breed. In contrast to our finding, Chauhan et al., (2011) reported that seroprevalence was highest in chokla (64.44\%) \& Marwari (60.16\%) breed of sheep than crossbred sheep (40.00\%). Jalees et al., (2016) observed that Cholistani breed of sheep showed higher prevalence than rest of the breeds of sheep.

\section{Sample wise positivity by sandwich ELISA}

Out of 119 clinical samples, 37 (31.09\%) samples including 13 Nasal swabs, 3 conjunctival swabs, 7 oral swabs and 14 tissues were found positive. The overall positivity for PPRV was significant $(\mathrm{P}<0.05)$ among various clinical samples.

In the present study, we found presence of viral antigen in goat $63.16 \%$ (12/19), $43.75 \%$ (7/16), $17.5 \%(7 / 40)$ and $15.00 \%(3 / 20)$ in tissue, oral swab, nasal swabs and conjunctival swabs, respectively. However presence of viral antigen in sheep was $27.27 \%(6 / 22)$ and $100 \%(2 / 2)$ innasal swab and tissue, respectively (Table 4). 
In this study found more number of tissue samples $66.67 \%$ (14/21) positive by S- ELISA in small ruminant. Similar observations have also been made earlier from studies of Gujarat, $(95.83 \%)$ by Ranaware et al., (2013) and $87.17 \%$ by Sakhare (2019).

Among tissue samples, Rajeshwari et al., (2000) concluded that spleen $(63.68 \%$ positivity) is the choice of material for antigen detection compared to lymph node and lung, which revealed $51.95 \%$ and $48 \%$ positivity, respectively (Table 4-A). In present study, we found positivity of PPRV in $43.75 \%$ (7/16) in oral swabs and $20.97 \%(13 / 62)$ in nasal swabs by S-ELISA. These positivity corroborates with the finding of Mahajan et al., (2012) who reported that, the nasal swab samples recorded maximum number of positive samples $(57.96 \%)$ followed by ocular swabs $(53.38 \%)$, oral swabs (46.15\%) and blood samples $(42.30 \%)$, whereas least positivity was reported in rectal swab (19.23\%) samples. The results are also in line with Singh et al., (2004) who reported that maximum quantity of PPRV antigen is excreted in occular and nasal secretions which are the best ante-mortem material for diagnosis of PPR by sandwich ELISA. In present study we found presence of PPR viral antigen in sheep $27.27 \%(6 / 22)$ and $100 \%(2 / 2)$ in nasal swab and tissue respectively. The positivity corroborate with finding of Albayrak and Alkan (2009) who observed that the nasal and conjunctival swab samples are more valuable as diagnostic material from sheep with clinical symptoms. However, Haq et al., (2017) revealed only $18.75 \%$ (18/96) samples were positive for PPRV-specific antigen in anti-N monoclonal antibody-based sandwich-ELISA.

Comparatively higher positivity rate in tissue samples than other swabs as observed in the present study can also be explained by the fact, that it is possible that few of the animals might not be in viremic stage at the time of sample collection. As tissues are collected on post- mortem, the virus after causing sufficient damage to the level of death obviously remains in active growth phase and hence may turn out to be more positive (Chaudhary, 2009).

A total of 119 different clinical samples (nasal swabs, conjunctival swabs, oral swabs and lung, trachea, spleen, intestinal tissue) from goats and sheep were collected from Rajkot, Amreli and Bhavnagar districts of Saurashtra region of Gujarat for detection of PPR antigen by Sandwich ELISA. Out of 119 clinical samples, 37 samples were found positive in small ruminants by S-ELISA, giving an overall incidence rate of 31.09 percent. In Goat and sheep, 30.52\% (29/95) and 33.33\% $(8 / 24)$ samples were detected positive, respectively.

\section{References}

Abubakar, M.; Ali, Q. and Khan, H. A. (2008). Prevalence and mortality rate of peste des petits ruminants (PPR): possible association with abortion in goat. Tropical Animal Health and Production, 40: 317-321.

Abubakar, M.; Mahapatra, M.; Muniraju, M.; Arshed, M. J.; Khan, E. H.; Banyard, A. C.; Ali, Q. and Parida, S. (2017). Serological detection of antibodies to Peste des petits ruminant's virus in large Ruminants. Transboundary and Emerging Diseases, 64(2):513-519.

Afera, B.; Hussien, D. and Amsalu, K. (2014). Seroprevalence of Peste Des Petits Ruminants in Goats of Southern Parts of Tigray Region. Global Veterinaria, 12(4): 512-516.

Albayrak, H. and Alkan, F.(2009). PPR virus infection on sheep in Black-sea region of Turkey: epidemiology and diagnosis by RT-PCR and virus isolation. Veterinary

Research 
Communications, 33: 241-249.

Balamurugan, V.;Saravanan, P.; Sen, A.; Rajak, K. K.; Bhanuprakash, V.; Krishnamoorthy, P. and Singh., R. K.(2011). Sero-epidemiological study of peste des petits ruminants in sheep and goats in India between2003and 2009. Revue Scientifique et Technique,30(3): 889-896.

Balamurugan, V.; Saravanan, P.; Sen, A.; Rajak, K. K.; Venkatesan, G.; Krishnamoorthy, P.; Bhanuprakash, V. and Singh, R. K. (2012). Prevalence of peste des petits ruminants among sheep and goats in India. Journal of Veterinary Science, 13(3): 279-285.

Balamurugan, V.; Krishnamoorthy, P.; Raju, D. N.; Rajak, K. K.; Bhanuprakash, V.; Pandey, A. B.; Gajendragad, M. R.; Prabhudas, K. and Rahman, H.(2014). Prevalence of Peste-des-petitsruminantvirus antibodies in cattle, buffaloes, sheep and goats inIndia.Indian Journal of Virology, 25(1): 85-90.

Chauhan, H.; Chandel, B.; Kher, H.; Dadawala, A. and Agrawal, S. (2009). Peste des petits ruminants infection in animals. Veterinary World, 2: 150155.

Chauhan, H. C.; Lambade, P. S.; Sen, A.; Dadawala, A. I.; Ranaware, P. B.; Chandel, B.; Jhoshi, D. V.; Patel, S. S.; Kumar, P.; Shah, N. M. and Kher, H. N. (2011). The use of pathological and histopathological techniques in the diagnosis of peste des petits ruminants in India. Veterinarian Italiana, 47(1): 41-47.

Choudhary, Pooja; Jhala, M. K. and Kanani, A. N. (2009). Incidence of PPR virus in Gujarat by s-ELISA and molecular detection by $\mathrm{F}, \mathrm{N}$ and $\mathrm{H}$ gene based RT-PCR.Royal Veterinary Journal of India,5(1/2):1-4.

Diallo, A. (2003). Featured Articles. http://www.indiaveterinarycommunity. com/prof perspective / featured article/Feb-03/art-diallo.asp.

El-Rahim, I. H. A.; Sharawi, S. S. A.; Barakat, M. R. and El-Nahas, E. M. (2010). An outbreak of peste des petits ruminants in migratory flocks of sheep and goats in Egypt in 2006. Scientific and Technical Review of the Office International des Epizooties, 29 (3): 655-662.

Haq, AdilAnamul; Ramasamy, Santhamani; Chakravarti,Soumendu; Yadav, Ajay Kumar; Rajak, KaushalKishor; Upmanyu, Vikramaditya; Sinha, Dharmendra Kumar; Malik, Yashpal Singh and Singh, Rabindra Prasad.(2017). Investigation on Peste des Petits ruminants Outbreak in Goats ofBareilly District of Uttar Pradesh. Indian Journal of Immunology and Immunopathology, 19(1): 47-54.

Hinshu, T. V.; Kher, H. N.; Chandel, B. S. and Jhala, M. K. (2001). Seroprevalence of Peste des petits ruminants (PPR) in Gujarat. Indian Journal of Comparative Microbiology, Immunology and Infectious Diseases, 22 (1): 81.

Jalees, M. M.; Hussain, I.; Arshad, M.; Mohammad, G. and Qaiser, M. K. (2016). Seroprevalence and molecular detection of Peste des Virus (PPRV) in different breeds of sheep and goat of Punjab (Pakistan). Pakistan Journal of Life Social Science, 14 (1): 12-17.

Kanani, A.; Sutariya, P.; Shukla, R. and Shukla, R. (2006). Seroprevalence of Peste des petits ruminants(PPR) in small ruminants ofGujarat State. Indian Journal of Field Veterinarians, 1(4): 22- 23.

Kataria, A. K.; Kataria, N. and Gahlot, A. K. (2007). Large scale outbreak of peste des petits ruminants virus in sheep and goats in Thar Desert of India. 
Slovenian Veterinary Research, 44: 123-132.

Kozat, S. and Sepehrizadeh, E. (2017). Peste Des Petit Ruminants-A review. Journal of Istanbul Veterinary Science, 1(2): 47-56.

Kulkarni, D. D.; Bhikane, A. U.; Shaila, M. S.; Varalakshmi, P.; Apte, M. P. and Narladkar, B.W. (1996). Peste des petits ruminants in goats in India. Veterinary Record, 138 (8): 187-188.

Lefevre, P. C. and Diallo, A. (1990). Peste des petits ruminants. Revue scientifiqueet technique, 4:935-981.

Libeau, G.; Prehaud, C.; Lancelot, R.; Colas, F.; Guerre, L.and Bishop, D.H. (1995). Development of a competitive ELISA for detecting antibodies to the peste des petits ruminants virus using a recombinant nucleoprotein. Research in Veterinary Science, 58:50- 55.

Mahajan, S.; Agrawal, R.; Kumar, M.; Mohan, A. and Pande, N. (2012). Risk of seroconversion to peste des petits ruminants (PPR) and its association with species, sex, age and migration. Small Ruminant Research, 104(1): 195-200.

Mahajan, S.; Agrawal, R.; Kumar, M.; Mohan, A. and Pande, N. (2013). Incidence of Peste des petits ruminants in nomadic sheep and goat of Jammu region. Veterinary World, 6(7): 384-387.

Malik, Y. S.; Singh, D.; Chandrashekar, K. M.; Shukla, S.; Sharma, K.; Vaid,N. and Chakravarti,S.(2011). Occurrence of dual infection of Peste-Des-PetitsRuminants and goat pox in indigenous goats of Central India.Trans boundary and Emerging Diseases, 58: 268-273.

Mohapatra D. (2015). Seroprevalence of peste des petits ruminants virus in vaccinated sheep and goat flock in coastal odisha, M.V.Sc. thesis, Orissa University of Agriculture and technology, Bhubaneshwar. India.
Munir, M.; Saeed, A.; Abubakar,M.; Kanwal, S. and Berg, M. (2015). Molecular characterization of Peste des Petits Ruminants viruses from outbreaks caused by unrestricted movements of small ruminants in Pakistan. Transboundary and Emerging Disease, 62(1): 108-114.

Nagraj (2006). Assessment of differentgene target for detection of Peste des petits ruminants by RT-PCR and Sequence analysis of $\mathrm{F}$ and $\mathrm{N}$ gene segments. M.V.Sc. thesis submitted to Anand Agricultural University, Anand, India.Pp:124.

Raghavendra, A. G.; Gajendragad, M. R.; Sengupta, P. P.; Patil, S. S.; Tiwari, C. B.; Balumahendiran, M.; Sankri, V. and Prabhudas, K. (2008). Seroepidemiology of peste des petits ruminants in sheep and goats of southern peninsular India. Scientific and Technical Review of the Office International des Epizooties, 27: 861867.

Rahman, M. S.; Islam, M. S.; Sultana, M. S. and Kabir, F. (2015). Study on prevalence of Peste Des Petits Ruminants (Ppr) in goats. Bungladesh Research publications Journal, 11(1): 54-58.

Rajeshwari, K. R.; Rama sastry, P. and Ramakrishna Rao, M. (2000). PPR in small ruminants in Andhra Pradesh. Indian Veterinary Journal, 77:373375.

Ranaware, B. P.; Chauhan, H. C. ; Shah, N. M.; Chandel, B. S.; Pankaj Kumar, Dadawala, A. I.; Patel, S. S. and Parekar S. S. (2013). Seroepidemiology of Peste Des Petits Ruminants (PPR) in Small Ruminants in Gujarat. Indian Veterinary Journal, $90(4): 9-10$.

Sakhare, P. S. (2019). Detection, isolation and molecular characterization of Peste des 
petites ruminants virus in small ruminants of south Gujarat. Ph.D. Thesis, Vanbandhu College of Vet. Sci. \& A.H.,Navsari Agricultural University, Navsari. India.

Sakhare P. S.; Kalyani I. H.; ViholPriti; Sharma K. K. and Makwana Pushpa (2019). Symtomatology and Pathomorphological changes in outbreak of peste des petitis ruminants in small ruminants. IntasPolivet, 20(1) : 118-122.

Santhosh, A.; Raveendra, H.; Isloor, S.; Gomes, R.; Rathnamma, D.; Byregowda, S.; Prabhudas, K. and Renikprasad, C.(2009). Seroprevalence of PPR inorganized and unorganized sectors in Karnataka.Indian Veterinary Journal, 86: 659- 660.
Shaila, M. S.; Shamaki, D.; Forsyth, M. A.; Diallo, A.; Goatley, L.; Kitching R. P. and Barrett T. (1996). Geographic distribution and epidemiology of peste des petits ruminant viruses. Virus Research, 43: 149-153.

Singh, R. P.; Saravanan, P.; Sreenivasa, B. P.; Singh, R. K. and Bandyopadhyay, S. K. (2004). Prevalence and distribution of peste des petits ruminants (PPR) virus infection in small ruminants of India. Scientific and Technical Review of theOffice International des Epizooties, 23(3):807-819.

Yesilbag, K.; Yilmaz, Z.; Golew, E. and Ozkul, A. (2005). Peste des petits ruminants outbreak in western Turkey. Veterinary Record, 157: 260-261.

\section{How to cite this article:}

Tajpara, M. M., A. N. Kanani, H. H. Savsani, J. B. Kathiriya, P. V. Gohil, D. R. Patel and Shah, N. M. 2021. Incidence of Peste Des Petits Ruminants Virus infection in Small Ruminants of Saurashtra Region of Gujarat State. Int.J.Curr.Microbiol.App.Sci. 10(07): 257-269. doi: https://doi.org/10.20546/ijcmas.2021.1007.027 